\title{
SECTION 16(b) AND CONVERTIBLE SECURITIES: AN ANALYSIS OF THE DEFINITION OF "CLASS"
}

When Thomas Corcoran told the Senate Committee on Banking and Currency that section 16 of what was to become the Securities Exchange Act of $1934^{1}$ was a "crude rule of thumb," 2 he not only made legislative history that has become trite through repetition, but also set the stage for a battle over just how crude section 16 should really be. The battle, which has centered on the definitions of "purchase" and "sale" as used in section $16(b),{ }^{3}$ is far from over, but the start of a new skirmish may have been signalled by the Second Circuit's opinion in Chemical Fund, Inc. v. Xerox Corp. ${ }^{4}$ where the court sought to give meaning to section 16's phrase "class of any equity security" when convertible debentures are the "equity security" involved.

One of the few undisputed statements that can be made about section 16 is that it was intended to prevent profit-taking on advance information not generally available to the public. Prevention of insider trading was accomplished primarily through two subsections. Subsection (a),${ }^{5}$ the disclosure provision of section 16 , requires insiders to file a statement of ownership of securities with the Securities Exchange Commission. Those subject to the filing requirement are identified as directors, officers, and beneficial owners of more than ten per cent of any class of equity security. The inclusion of the ordinary investor among those considered insiders is justified on the theory that an owner of as much as ten per cent of any class "is as much an insider as an officer or director" and "normally is, as a practical matter of fact, a director." " Subsection (b), the purging provision, makes these insiders liable to the corporation for profits realized from transactions involving a purchase and sale (or sale and purchase) of any equity security of the issuer within a six-month period. Thus, the basic logic of section 16 seems clear: since the purpose is to prevent misuse of

115 U.S.C. $\$ 78$ (1964).

2 Hearings on S. Res. 84, 56, and 97 Before the Senate Comm. on Banking and Currency, 73d Cong., 1st Sess. 6557 (1934) [hereinafter cited as Hearings].

3 Securities Exchange Act of 1934, $\$ 16(\mathrm{~b}), 15$ U.S.C. $\$ 78 \mathrm{p}$ (b) (1964); see, e.g., Blau v. Lamb, 363 F.2d 507 (5th Cir. 1966), cert. denied, 385 U.S. 1002 (1967); Blau v. Max Factor \& Co., 342 F.2d 304 (9th Cir.), cert. denied, 382 U.S. 892 (1965) ; Ferraiolo v. Newman, 259 F.2d 342 (6th Cir. 1958), cert. denied, 359 U.S. 927 (1959); Park \& Tilford, Inc. v. Schulte, 160 F.2d 984 (2d Cir.), cert. denied, 332 U.S. 761 (1947).

\&377 F.2d 107 (2d Cir. 1967).

5 Securities Exchange Act of 1934, §16(a), 15 U.S.C. \$78p(a) (1964).

${ }^{6}$ Hearings 6556.

7 Securities Exchange Act of 1934, §16(b), 15 U.S.C. §78p(b) (1964). 
inside information, those most likely to have access to such information, either from participation in corporate policy-making or administration or from influence with such participants, should be the ones subject to regulation. $^{8}$

With respect to holders of convertible securities, ${ }^{9}$ however, the apparent simplicity of section 16 is misleading. The difficulty lies in deciding on the relevant "class" for the purpose of determining whether the owner is a ten per cent holder and therefore subject to the trading restrictions. There are three possibilities: (1) the relevant "class" could be the class of convertible securities, so that percentage ownership is calculated on the basis of only the convertibles outstanding; (2) the "class" could be defined to include all outstanding securities of the class for which the convertible is exchangeable; ${ }^{10}$ or (3) "class" could be taken to refer to both the class of convertibles and the class of underlying security, so that a holder of convertibles would be a section 16 insider if he held, or would hold after conversion, ten per cent of either class.

The phrase "class of any equity security" had received little judicial interpretation prior to the Chemical Fund decision. Rule $16 \mathrm{a}-2$, before a recent amendment, ${ }^{11}$ had merely indicated that the percentage ownership of a class was to be determined on the basis of the "total amount of such class outstanding," 12 exclusive of any securities of the class held by or for the account of the issuer. Apparently, it was assumed that convertibles were a class separate from the underlying security.

The only case construing "class" before Chemical Fund was Ellerin v. Massachusetts Mutual Life Insurance Co., ${ }^{13}$ decided eight years earlier. There, the Second Circuit had faced the question whether a "series" of preferred stock constituted a "class" for the purposes of section 16. Finding no prior case law, no specific statutory definition, and no legislative history on the issue, the court concluded that "class" was to be understood in the "ordinary and generally accepted sense according to the common usage of the day

\section{See Hearings 7441-43.}

9 The convertible security, generally speaking, is a bond [or debenture] or preferred stock which at the option of the holder is exchangeable under specified terms and conditions for the common shares of the same corporation.

C. Pilcher, Raising Capital With Convertible Securities 2 (1955).

10 In order to determine percentage ownership, the number of shares of the underlying security outstanding would be added to the number of shares into which the owner of the convertibles could convert. This figure would then be divided into the number of shares into which the convertible owner could convert plus the number of shares of the underlying security held by such owner.

11 See text accompanying note 32 infra.

1217 C.F.R. $\$ 240.16 \mathrm{a}-2$ (1964).

13270 F.2d 259 (2d Cir. 1959). 
[1934] in the legal and financial worlds." ${ }^{14}$ Applying this test, the court held that a series could not be considered a class for the purposes of section 16 since, in common usage, "class" and "series" were ustrally differentiated, a "series" being considered a part of a "class." The SEC had submitted an amicus curiae brief arguing that each series involved was a "class," 15 but after the adverse decision it made no further attempt at definition through its rule-making power. ${ }^{16}$

Judicial determination of the "class" appropriate for convertible securities was first required in the Chemical Fund case. The Second Circuit was confronted with the question whether Chemical Fund, the owner of more than ten per cent of the outstanding convertible debentures of Xerox Corporation, was the owner of ten per cent of a "class of any equity security" and thus liable for short-swing profits under section 16(b), even though it would hold less than ten per cent of the Xerox common stock if it converted its debentures. Under the Ellerin rule that "class" should be construed according to its "common usage," and under section 3(a)(11) of the Act, ${ }^{17}$ which includes in the definition of "equity security" any security convertible into an equity security, it would seem clear that debentures convertible into common stock are a "class of equity security" within the meaning of the Act, and the district court so held. ${ }^{18}$ The court of appeals, however, while conceding that convertible debentures are "equity securities," held that they do not constitute a "class of equity security" for the purposes of determining percentage ownership and liability under section $16(\mathrm{~b}) .^{19}$

The court was distressed by the "anomaly" that would have resulted from holding Chemical Fund liable: a potential owner of less than three per cent of the common stock would be accountable for short-swing profits while an actual owner of 9.99 per cent of the common would be immune from such liability. ${ }^{20}$

The court also felt that section 16 was intended to apply only to "stockholders" and that holders of "debentures as such" were not in-

14 Id. at 262. The court stated:

But the very absence of congressional direction or guidance suggests that Congress thought the meaning of the phrase ... was reasonably clear and it was using familiar terms ....

$1 \overline{5}$ See id. at 261 .

16 See Securities Exchange Act of 1934, §§3(b), 23(a), 15 U.S.C. \$§ 78c(b), $78 w$ (a) (1964). Pursuant to $\$ 3(\mathrm{~b})$ of the Act, the SEC did, however, issue rule $3 \mathrm{~b}-2$, 17 C.F.R. $\$ 240.3 \mathrm{~b}-2$ (1964), defining "officer" to mean "a president, vice-president, treasurer, secretary, comptroller, and any other person who performs for an issuer, whether incorporated or unincorporated, functions corresponding to those performed by the foregoing officers."

1715 U.S.C. \& 78c(a) (11) (1964). 1966)

18 [1964-1966 Transfer Binder] CCH FEd. SEC. L. REP. đ91,653 (W.D.N.Y.

19377 F.2d 107, 110 (2d Cir. 1967).

20 Of course, such an anomaly is inherent in the congressional scheme, which is based on class ownership. Those who own $10 \%$ of small classes will be subject to $\$ 16$, while those who own $9 \%$ of larger classes-and who may have a far greater investment in the company-will not face such liabilities. 
cluded within its scope. ${ }^{21}$ The court based its conclusion on its findings that (1) nowhere in the hearings preceding passage of the Act was there any indication that debenture holders as such were to be included; and (2) bondholders, originally included within section 16(a), were excluded from the final draft. ${ }^{22}$ This exclusion, the court noted, was "apparently" due to protests such as those contained in a letter from the National Association of Mutual Savings Banks stating that "[b]ondholders as such exercise no control over the management of the issuer and its policies." 23 Equating corporate control with voting power, the court reasoned that "stockholders owning more than 10 percent of the voting stock of the company, if not in control, would be closely advised, as their votes usually elected the directors who in turn elected the officers, where these were not elected directly by the stockholders." 24 The court concluded that convertible debentures are considered "equity securities" solely because of the power to convert into common, and the determination of percentage ownership should therefore be calculated on the percentage of the common the owner would hold following conversion. ${ }^{25}$

A more careful analysis of the legislative history, however, shows that it is in fact inconclusive on the issue whether convertible debentures should be considered a separate "class of equity security." The fact that debentures were not mentioned in the hearings is as indicative of inclusion as it is of exclusion. The letter from the National Association of Mutual Savings Banks was neither discussed nor referred to in the hearings, but was merely appended with several other letters discussing various aspects of the bill. Aside from the revision itself, that letter appears to be the sole evidence of any concern over the distinction between stocks and bonds. The revision of the bill may or may not have been for the reasons stated in the letter; the Senate Report substituting the revision for the original bill does not deal with the question. ${ }^{20}$

Contrary to the inference drawn by the court, the revision can be read to have expanded coverage under section $16(\mathrm{~b})$ to include holders of convertible debentures. The original bill distinguished between subsections (a) and (b) by using the term "securities" in (a) (which section 3 defined to include bonds and debentures) while using the term "stock" in (b), implying the exclusion of bonds and debentures. ${ }^{2 \pi}$

21377 F.2d at 110.

22 Id.

23 Id. at $110 \mathrm{n} .4$.

24 Id. at $110-11$.

$25 I d$.

26 See S. Rep. No. 792, 73d Cong., 2d Sess. (1934). (1934):

27 See S. 2693, 73d Cong., 2d Sess. (1934), reprinted in 78 CoNG. REC. 2265, 2268

$\$ 15$ (a) Every director, officer, or owner of securities, owning as of record and/or beneficially more than 5 per cent of any class of securities of any 
In the revised bill, the term "equity security" was substituted in both sections, ${ }^{28}$ and this term was defined to include any security convertible into a stock. Thus, while convertible debentures would not have been included in section (b) of the original draft, they were expressly included in the final draft. While the revision had the effect of narrowing the scope of subsection (a) from "securities" to "equity securities" (thereby excluding nonconvertible bonds and debentures), it also expanded the scope of subsection (b) by substituting "equity securities" (defined to include convertible debentures and bonds) for "stock."

\section{RuLE 16a-2}

In its amicus brief in Chemical Fund the SEC argued that convertible debentures should be considered a separate class under the Ellerin rationale since they "are not considered to come within the same class as common stock in the ordinary and generally accepted sense." "29 The court summarily rejected this argument on the ground that while in Ellerin the court had no statutory history to guide it, in this case the "purpose of section 16(b) to impose liability on the basis of actual or potential control is clear and we should give it effect." 30

The court's opinion did not, however, deter the SEC from amending rule $16 a-2^{31}$ to explain specifically in which class the owner of convertible securities belongs for the purpose of computing percentage ownership under section 16(a). The amendment added the following paragraph to the existing rule:

In determining for the purpose of Section 16(a) of the Act whether a person is the beneficial owner, directly or indirectly, of more than ten percent of any class of equity securities, such person shall be deemed to be the beneficial owner of securities of such class which such person has the right to acquire ... through the conversion of presently convertible securities. The securities subject to such . . . conversion privileges held by a person shall be deemed to be outstanding for the purpose of computing, in accordance with paragraph

issuer . . . shall file .... (Emphasis added.)

\$15(b) It shall be unlawful for any director, officer, or owner of securities, owning as of record and/or beneficially more than 5 percent of any class of stock of any issuer .... (Emphasis added.)

\$3(10) The term "security" means any note, stock, treasury stock, bond, debenture, certificate of interest.

28 See S. 3420, 73d Cong., 2d Sess. (1934).

29 Brief for SEC as Amicus Curiae at 7, Chemical Fund, Inc. v. Xerox Corp., 377 F.2d 107 (2d Cir. 1967).

30377 F.2d at 111.

3133 Fed. Reg. 8774, amending 17 C.F.R. $\$ 240.16$ a-2 (1964). 
(a), the percentage of outstanding securities of the class owned by such person but shall not be deemed outstanding for the purpose of computing the percentage of the class owned by any other person. This paragraph shall not be construed to relieve any person of any duty to comply with Section 16(a) of the Act with respect to any equity securities consisting of . . . convertible securities which are otherwise subject as a class to that section. ${ }^{32}$

At first glance it appears that the Commission merely adopted the holding of Chemical Fund in providing that holders of convertibles are deemed owners of the class they have a privilege to acquire by conversion. However, the amendment differs from the court's holding in two respects: (1) it is specifically limited to the "purposes of Section 16(a)," and (2) it indicates that the owner of convertibles is to be considered the owner of securities within the classes of both the underlying stock and the convertibles themselves. These differences are apparent from the SEC's releases. In the release proposing the amendment, the Commission stated:

Under the present Rule 16a-2 the Commission has taken the position that ownership reports are required for persons owning in excess of 10 per cent of a class of registered securities convertible into equity securities of the issuer. Although the United States Court of Appeals for the Second Circuit has held in Chemical Fund v. Xerox Corp. . . . that such a class should not be considered a separate class of equity securities for the purposes of determining liabilities for short-swing profits under Section 16(b), the Commission does not believe, in light of the differing purposes of Section 16 (a), that that decision was determinative of the obligation to file ownership reports. The Commission, therefore, will continue to take the position that reports are required of persons holding 10 per cent of a class of registered securities convertible into equity securities. ${ }^{33}$

And in the release promulgating the amendment the Commission issued the following caveat:

The amended rule does not purport to be determinative of the question whether transactions in . . . convertible securities may give rise to liabilities under Section $16(\mathrm{~b})$ of the Act. The Commission regards that question as properly

33 Securities Exchange Act Release No. 8202 (Dec. 6, 1967), 32 Fed. Reg. 18063 
being one for the determination of the courts independently of Rule $16 \mathrm{a}-2 .^{34}$

Thus, although the Commission has not "acquiesced" in the Chemical Fund formula, neither has it used its rulemaking power ${ }^{35}$ to attempt to overrule the decision as the standard for subsection (b) liability.

The net effect of the amendment appears to be as follows: all holders of ten per cent of the outstanding convertibles are still required to file reports under section 16 (a), as they presumably were before Chemical Fund put this in doubt. What is new is that a person who owns less than ten per cent of the convertibles, but who would own ten per cent or more of the underlying security upon conversion is now required to file reports under section 16(a). This is an obligation that, prior to the amendment, would not have existed until actual conversion. It also appears that under the amendment a person holding securities of a class exempt from registration under section $12^{36}$ and therefore not previously subject to section $16(a){ }^{37}$-even if he held more than ten per cent of that class-is now required to file reports if that security is convertible into ten per cent of a registered equity security. That person is now deemed to be the "owner" of the registered security.

It appears the SEC was justified in its action. Admittedly, the language of section 16 suggests that subsections (a) and (b) apply to the same persons: subsection (a) applies to "every person who is directly or indirectly the beneficial owner of more than ten per centum of any class of any equity security," and subsection (b) applies to "such owner," thereby referring back to the definition in subsection (a). It seems, therefore, that subsection (b) has no meaning unless reference is made to subsection (a), and that identical coverage was intended. $^{38}$ However, the statute itself provides that the Commission may, by rules and regulations, exempt transactions from $16(\mathrm{~b}) ;^{39}$ the presence of an exempting power limited to subsection (b) suggests that, despite the verbal interdependence of the subsections, Congress (1968).

34 Securities Exchange Act Release No. 8325 (June 6, 1968), 33 Fed. Reg. 8774

35 See note 16 supra.

36 Securities Exchange Act of 1934, $\$ 12(\mathrm{~g}), 15$ U.S.C. $\$ 78 \mathrm{l}(\mathrm{g})$ (1964).

37 Section 16 (a) applies only to those $10 \%$ holders whose securities are "registered pursuant to [this Act]." 15 U.S.C. \$78p (a) (1964).

38 It might be noted that the Second Circuit in Chemical Fund evidently thought it was supplying a rule of calculation for both subsections (a) and (b). It repeatedly referred to its definition as relating to "section 16," rather than just section 16 (b). See, e.g., 377 F.2d at 108, 112. This apparent intention raises the question whether an owner of $10 \%$ of the convertibles who refuses to file 16 (a) reports would be liable under $\$ 32$ of the Act (15 U.S.C. $\$ 78 f$ (a) (1964)) or would have a valid defense of exemption from filing under Chemical Fund.

3915 U.S.C. $\$ 78 \mathrm{p}(\mathrm{b})$ (1964). 
contemplated the possibility of differing scopes for each. Indeed, a more expansive application of subsection (a) than subsection (b) is justified by several policies underlying section 16 .

First, subsection (a) provides for the publication of transactions by insiders for the purpose of deterring abusive practices. ${ }^{40}$ Concomitantly, it provides a disclosure device whereby the public can gain valuable information about investment changes made by those likely to be well informed about the prospects of the corporation. ${ }^{41}$ And finally, until the law with respect to section $16(\mathrm{~b})$ is accepted as settled, a certain amount of "overkill" may be necessary under 16(a), so that doubtful transactions will be made public and test suits can be brought. Thus, the need for this information, especially when viewed in light of the relatively slight burden reporting imposes upon the stockholder, appears to justify a broader application of subsection (a).

\section{The Appropriate "Class" for Convertible Securities}

While the differing purpose of section 16(a) may justify the expansive definition of "class" in rule 16a-2, the question remains what is the appropriate class for $16(b)$ purposes. Examination of the probable reasons for Congress's choice of "class of equity security" as a touchstone for measuring insider status sheds light on the propriety of the Chemical Fund definition.

Limiting section 16 to "equity securities" advances the policies of that section for a number of reasons. While equity securities do not necessarily have voting powers, evidently it was thought that the voting power normally attached to equity securities (as distinct from debt securities) provides the leverage with which an owner can either influence the flow of public information about the corporation, and thereby manipulate the stock prices to his advantage, or elicit advance information from directors who depend on his votes to remain in office. Perhaps it was thought that, even without voting power, equity

${ }^{40}$ H.R. Rep. No. 1383, 73d Cong., 2d Sess. 9 (1934), discussing $\$ 16$ (a) (then $\$ 15(\mathrm{a})$ and including $5 \%$ holders):

Because it is difficult to draw a clear line as a matter of law between truly inside information and information generally known by the better-informed investors, the most potent weapon against the abuse of inside information is full and prompt publicity. For this reason, that bill requires the disclosure of the corporate holdings of officers and directors and stockholders owning more than 5 percent of any class of stock, and prompt disclosure of any changes that occur in their corporate holdings.

41 See id.:

Under subsection (a) directors and officers of the issuer of a registered equity security . . . and holders of more than 5 percent of any class of a registered equity security ... are required at the time of registration to file with the Commission a list of their holdings of the issuer's securities and to file monthy reports of their dealings in such securities. This is to give investors an idea of the purchases and sales by insiders which may in turn indicate their private opinion as to the prospects of the company. 
security holders as a group are more likely to be privy to inside information merely as a corporate gesture of goodwill than are holders of debt securities. Another distinguishing feature of equity securities lies in their volatility; equity securities are subject to greater price fluctuations than are debt securities. Thus, the owner of a large block of equity holds the threat of depressing prices by block selling, while the bondholder generally lacks this power because of the relative stability of the bond market. These considerations suggest that equity securities are far more suitable for section 16 treatment, and justify the debt-equity distinction drawn by Congress.

While the policies behind limiting section 16 to equity securities seem relatively clear, Congress's decision to define "insider" by the percentage ownership of a class of equity securities may seem puzzling. Insider status could have been measured in terms of percentage ownership of the dollar value of the total equity of a corporation, or the percentage control of the aggregate voting power of all classes. Indeed, the whole concept of percentage ownership could have been replaced by an absolute dollar value standard, on the theory that anyone with a given amount of money tied to one enterprise would likely be so concerned with the company's future that a strong link, or at least the likelihood of substantial contact, with management would be a prerequisite to continued investment in the corporation.

By ignoring these alternatives and adopting the class standard, Congress opened up the possibility of seemingly anomalous results in the imposition of 16 (b) liability. Since the various classes of securities in any corporation may differ vastly in size and price, the percentage-of-class ownership standard will reach some investors with relatively low total equity ownership because their holdings are concentrated in smaller classes, while at the same time fail to include relatively large total equity owners who own securities of a larger class. This type of disparity seemed to the court in Chemical Fund a glaring anomaly because the holder of ten per cent of convertible debentures would hold a mere three per cent of the common were he to convert. 42

There are, however, two reasons why Congress may have been willing to tolerate this disparity. First, voting on corporate matters often takes place by class; it is not uncommon for a state statute or corporate charter to provide for voting on a class basis, with a majority vote needed in each class or in some combination of classes in order to authorize action or elect an officer. ${ }^{43}$ Thus, if a majority vote is needed in each class, a strong position in any one class makes

42 See 377 F.2d at 111.

43 For examples of state statutes which require voting on a class basis, see Inl. ANn. Stat. ch. 32, \$157.54 (Smith-Hurd Supp. 1967); N.J. Stat. ANN. \$ 14A :5-11 (1968) ; N.Y. Bus. CoRP. \$ 804 (McKinney 1963) ; PA. Stat. AnN. tit. 15, $\S 1505$ (1967). 
the owner an important figure to the corporation's management. $\mathrm{He}$ is a potential obstacle to management policy or to the election of officers and directors, and thus is a likely recipient of favors and valuable information from the power centers of the corporation.

Even aside from voting power, a sizeable percentage holding in even a small class may confer influence and access to information. Since each class of securities tends to have its own market, separated from the markets of other classes by its own unique attributes and privileges, the sale of a significant portion of any class is likely to have a consider. able effect on the price of that class. A threat to adversely affect that price, even when the class is relatively small, could be very significant to management. Where the price of one type of security is low, it becomes more expensive to raise capital by that type of security since the amount of equity (or shares of the security) the corporation must give each dollar it receives is higher. Also, a threat to depress the price of any corporate security is a threat to diminish the value of any similar securities held personally by management, regardless of the overall size of the class of those securities. Thus, market power in addition to voting power makes percentage ownership of any class quite relevant to determining insider status.

If voting and market power are the elements that make "class" relevant to the policies of section 16 , it is arguable that any definition of "class" should include only those groupings of securities which possess the voting and market characteristics set forth above. Thus, in determining the proper "class" for convertible securities, the initial inquiry should be into the convertibles' voting power. However, a voting analysis is especially difficult with convertibles because their voting powers can derive from a number of sources and vary with the particular type of security. A convertible may have an ordinary vote as part of the class of convertibles, as in the case of a voting preferred stock convertible into common stock. In the more common situation, the convertible has no general voting power prior to conversion-as is the case with most convertible debentures. Even in such a case, though, the debenture may have potential voting power since it will usually be convertible into some kind of voting stock. Moreover, the corporate charter or statutes of the state of incorporation may provide for voting rights prior to conversion in the event of a contingency such as continued nonpayment of dividends, or on questions of extraordinary significance to the corporation. ${ }^{44}$ Even if such votes are not presently exercisable, the rights upon conversion are exercisable at the will of the convertible holder, and the preconversion rights represent a threat of significant opposition at some important time in the future. Such potential voting rights would most likely command significant influence with present power-holders in the corporation. The voting-power

14 See, e.g., Der. Cone Ans. tit. 8, \$§221, 242 (Supp. 1966). 
analysis is further muddled by the fact that preconversion voting rights may provide for a vote as part of a separate class of convertibles, or, instead, a vote equal to that of the stock into which they are convertible.

The result of a voting-power analysis of the appropriate "class" for convertible securities, then, will necessarily depend not only on whether the convertibles are debentures or voting stock, but also on the specific provisions of the state's corporation law and the particular corporate charter. Where the only voting rights, present or potential, are exercisable as and measured against votes of the underlying security, the convertible security should be viewed as part of the class of underlying securities for the purpose of calculating ten per cent ownership. However, to the extent that the voting rights are exercisable as convertible security votes, distinct from those of the underlying security, the convertible securities should be considered a separate "class." If the voting rights may be exercised in both forms, it would be appropriate to treat the convertibles as members of both classes.

An analysis of the market power of the holder of convertible securities leads to more definite results than does the voting-power analysis. The extent of power conferred by the threat to sell the convertibles must be evaluated in light of the fact that there are two kinds of securities involved: the convertible and the underlying security. If the price of the underlying security rises sufficiently to allow a profit upon conversion, the underlying security exercises "sympathetic price control" 45 over the market value of the convertible. If the stock rises, the convertible will also rise. A sale of a large block of convertibles would probably not lower the price of the convertibles for any appreciable time. Although the initial effect of such a sale may be to lower the convertible's price, so long as the convertible is selling for a price lower than the total price of the underlying securities, arbitragers will buy the convertibles, ${ }^{46}$ thus driving the price back up. They can make an instant profit by selling the underlying security short and then covering their sales by converting upon receipt of the convertible security. ${ }^{47}$

If the number of shares of stock sold short, however, is sufficiently great, the effect may be to lower the price of such stocks. Whether

45 See G. Leffler \& L. Farwell, The Stock Market 624-25 (3d rev. ed. 1963) :

Let us suppose . . . that the stock rises sufficiently to warrant a profit to bondholders upon conversion. The conversion security is then said to exercise "sympathetic price control" over the market value of the bond. If the stock increases above the lowest conversion equivalent, the bond will automatically rise because of transactions by arbitragers. These arbitragers, who see a profit opportunity, will buy the bonds and convert into stock through an arbitrage transaction. Conversion equivalence will be maintained as the stock rises further.

$46 I d$.

$47 I d$. at 626. 
this occurs, of course, depends on the amount of shares of the underlying security that are sold, not on the total sales of the convertible. ${ }^{48}$ Therefore, the market power of a holder of convertible securities is directly related to the amount of the underlying security into which it is convertible (so long as the underlying security is exercising sympathetic price control). Whether the convertible holder has sufficient market power to rate insider status should be determined in light of his potential holdings of the underlying security. This is the result reached in Chemical Fund.

On the other hand, if it would not be profitable for the convertible holder to convert, the market value of the underlying security does not exercise control over the price of the convertible. This is usually the situation when a convertible is newly issued ${ }^{49}$ or if the price of the common has fallen below the conversion price. In such cases, the convertible stands largely ${ }^{50}$ on its own merits and, so far as market power is concerned, is similar either to a debenture or to a preferred stock without the conversion privilege, depending on the kind of convertible involved. Since ordinary debentures are not treated as equity securities under the Act, ${ }^{51}$ it would seem to follow that convertible debentures in the situation posited should be similarly treated. Furthermore, since their market would be as stable as a bond market they should not be considered a class of equity securities divorced from the underlying securities. Again this is the result that would be reached by following the Chemical Fund decision. For convertible preferred stock, however, the result should be different. The convertible preferred would be like preferred without the conversion privilege; but such securities are treated as "equity securities" under

$48 \mathrm{~A}$ sale of convertibles representing, for example, $10 \%$ of the underlying security would not necessarily have the same effect on the market value of the underlying security as would a sale of $10 \%$ of the security itself. Some purchasers may have bought in anticipation of a rise in the convertible; since they would not have sold the underyling security short they would not have to cover by converting and could simply sell the convertible itself to reap their gain. Others may have bought the convertible for investment purposes; they of course would not convert and sell but rather would hold onto the convertible.

49 See C. Pilcher, Raising Capital With Convertible Securities 46 (1955). American Telegraph \& Telephone has, however, issued convertibles with a conversion price lower than the market quotation for the underlying common stock. Id.

It should be noted that some corporations issue convertibles with delayed convertibility provisions. In other words, the debenture or preferred stock cannot be converted until some specified date after issuance. See PIlCEER, supra, at 50. During the time in which the conversion privilege is suspended, the underlying security may not exercise as much price control over the convertible, even if it would be profitable to convert. This would be due to the fact that arbitragers would not be able to sell short and cover their sales by converting after they bought the convertible. See text accompanying notes $46-47$ supra.

50 Some people may buy the convertible in anticipation of a price rise in the underlying security. In such cases, the convertible is not selling strictly on its merits as a debenture or preferred stock (depending on the kind of convertible involved). (1964).

51 See Securities Exchange Act of 1934, §3(a)(11), 15 U.S.C. $\$ 78 c$ (a) (11) 
the Act ${ }^{52}$ and their market would usually be the fluctuating market of an equity security. The market-power analysis dictates that convertible preferred shares be treated as a separate class when the underlying security is not exercising control over their price.

\section{Concluston}

In light of the voting-power and market-power analyses, the result in Chemical Fund is supportable. The convertible debentures in that case seemed to have no voting power prior to conversion and a threat to sell the debentures would confer market power only in relation to the underlying common stock. This would also seem to be true for most convertible debentures and bonds. The market power of the debenture holder would be in proportion to the amount of securities into which the debenture is convertible. Moreover, it would seem to be the exception rather than the rule for a convertible debenture to have voting power, actual or potential, exercisable in terms of the class of convertibles. It must be noted, however, that the convertible debenture is simply a contract; ${ }^{53}$ it is possible for the corporation to create a class of convertible debentures that would possess significant voting power. ${ }^{54}$ In such a case, the Chemical Fund rule of treating only the underlying securities as the "class" should not be followed. ${ }^{55}$ Rather, the holder of convertibles should be treated as a member of both the convertible class and the underlying class in the manner of rule $16 a-2.56$

Convertible preferred stock, however, may not fit into the Chemical Fund mould. Preferred stock is much more likely to have 1959).

52 Id.; See Ellerin v. Massachusetts Mut. Life Ins. Co., 270 F.2d 259 (2d Cir.

53 See A. Berle, Studies in the Law of Corporate Finance 132-34 (1928).

54 If there is any provision for the convertibles to vote as a class-even if such voting is contingent on some future event-it would appear appropriate to treat the convertibles as a separate class.

55 It would, of course, be desirable to have a rule for determining the appropriate class that does not vary with the attributes of the particular security. It is tempting to say that, as long as there is a possibility that some converible debentures will possess attributes that make them appropriate for treatment as a separate class, then all convertible debentures should be treated as separate classes. Section 16 was meant to be a "crude rule of thumb," wasn't it?

Such reasoning is specious. The "crudeness" of $\S 16$ is the irrebuttable presumption that those subject to the section are trading on inside information if they buy and sell securities of the corporation within a 6 month period. Because of the harshness of this presumption, it might be more appropriate to be particularly wary of including "innocent" people within its operation. If there were a statutory presumption, for example, that anyone found on premises where marijuana was being smoked would be conclusively presumed to have been smoking marijuana, one might be hesitant to say that someone found in the backyard or sidewalk was on the "premises."

An insider-by-insider approach has been adopted in the analogous area of who is an officer of a corporation for $\$ 16$ purposes, see note 16 supra. The disadvantages of such a case by case approach would seem to be outweighed by the advantages of a more flexible and equitable rule.

56 See text accompanying note 32 supra. 
voting power prior to conversion than would convertible debentures. In fact, preferred stock without the conversion privilege is treated as a "class of equity securities" under the Act; it may have been so treated for the very reason that preferred is likely to possess significant voting power. The market-power analysis also leads to the conclusion that convertible preferred should be treated as a separate class. If the convertible is newly issued, it is unlikely that the underlying security will have a significant impact on its price. ${ }^{57}$ Since the preferred market may be fairly volatile, as compared with the stable bond market, a sale of a significant amount of preferred at that time could markedly depress the market for convertible preferred. This, of course, would not be so if the underlying security was exerting price control over the preferred. But to have a rule that would treat the preferred as a separate class only when the total price of the underlying securities makes it unprofitable to convert would be unworkable. Day to day price fluctuations would affect the status of the holder. This fact, coupled with the concern of Congress for holders of preferred even without the conversion privilege, leads to the conclusion that the "class of equity securities" should be both the convertible preferred and the underlying stock-the same result reached under the Commission's rule $16 a-2$.

67 See note 49 supra and accompanying text. 